\title{
Neuroprotective Activity of Sesbania grandifolara Seeds Extract against Celecoxib induced Amnesia in Mice
}

\author{
Bhupesh Chander Semwal ${ }^{1 *}$, Madhuri Verma ${ }^{1}$, Yogesh Murti ${ }^{1}$, Harlokesh Narayan Yadav ${ }^{2}$
}

Bhupesh Chander Semwal ${ }^{*}$, Yogesh Murti ${ }^{1}$, Madhuri Verma ${ }^{1}$, Harlokesh Narayan Yadav ${ }^{2}$

'Department of Pharmacology Institute of Pharmaceutical Research GLA University, Mathura, Uttar Pradesh, INDIA. ${ }^{2}$ All India Institute of Medical Sciences New Delhi, INDIA.

\section{Correspondence}

\section{Bhupesh Chander Semwal}

Assis. Prof. Department of Pharmacology, Institute of Pharmaceutical Research GLA, University,Mathura, NH\#2 Delh Mathura, Highway P.O. Chaumuhan Pin-281406, Uttar Pradesh, INDIA.

Phone no: 09410575712

E-mail: bhupesh115@gmail.com

History

- Submission Date: 21-07-2017;

- Review completed: 26-08-2017.

- Accepted Date: 11-09-2017

DOI : 10.5530/pj.2018.4.125

Article Available online

http://www.phcogj.com/v10/i4

\section{Copyright}

(C) 2018 Phcog.Net. This is an openaccess article distributed under the terms of the Creative Commons Attribution 4.0 International license.

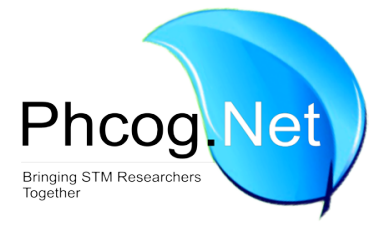

\begin{abstract}
Background: Sesbania grandiflora are characterized by their high anti-oxidant properties. The degeneration of neurons in Alzheimer disease mainly occurs because of high production of free radicals. However, the impact of Sesbania grandiflora on cholinergic system and oxidative stress parameter has not been investigated. Aim: The present study was designed to evaluate the neuroprotective effect of ethanolic extract of Sesbania grandiflora seeds in mice. Materials and Methods: The seeds of Sesbania grandiflora were powdered and subjected to successive extraction in Soxhlet apparatus. The different doses of ethanolic extract of Sesbania grandiflora seeds were evaluated for its neuroprotective activity against celecoxib induced amnesia in mice. Result and Conclusion: Phytochemical analysis of various extracts of Sesbania grandiflora revealed the presence of steroid, saponin, flavonoid, tannins and phenolic compounds. The ethanolic extract of Sesbania grandiflora significantly improves the memory of mice and reestablishes the amnesia induced by celecoxib. In addition to improvement in memory the extract treatment also decreases the activity of AchE and MDA and restore the antioxidant anzyme SOD, GSH and catalase in experimental animals. The results of our study showed that ethanolic extract of Sesbania grandiflora improve the cognition dysfunction in celecoxib treated mice through the modification in cholinergic system or by the blockage of oxidative stress and inhibition of AchE enzyme.
\end{abstract}

Key words: Acetylcholine, Celecoxib, Free radical, Morris water maze, Sesbania grandiflora.

\section{INTRODUCTION}

Alzheimer's disease (AD) is one of the most common form of dementia in which the neural injury is primarily in the hippocampus and cortex ${ }^{1}$ characterized by memory loss, language deterioration, poor judgment, impaired visuospatial skills etc. ${ }^{2}$ According to World Health Organization report 44 million of people are suffering from dementia worldwide, estimated that by the year 2050, 135 million of people will have dementia., The treatment of mild moderate stage of $\mathrm{AD}$ is only symptomatic ${ }^{5}$ however these authorized medications have disadvantages including extreme peripheral and central side effects, including git disturbance, insomnia, anxiety and depression. ${ }^{6}$ The unwanted side effects caused by authorized medications used to treat $\mathrm{AD}$ have constrained researcher to research more secure AChE inhibitors from natural sources. Natural products always have been used as a primary source of medicine from ancient time for the treatment of disease and injury. Still today in many developing country of World, huge number of population using medicinal plants for the treatment of neurodegenerative disorder. ${ }^{7-9}$

Sesbania grandiflora (SG) is a fast growing, small soft wooded tree, belongs to family papilonacea. Every part of SG is utilized for medicine in diuretic, emetic, fevers, headaches, smallpox, anemia, bronchitis, inflammation, leprosy, gout, rheumatism, anxiolytic, anticonvulsive, hepatoprotective and potent antidote for tobacco and smoking-related disease. ${ }^{10,11}$ Seeds of SG are possessing intellectual memory enhancer activity. ${ }^{12}$

\section{MATERIALS AND METHODS}

\section{Animals}

In the present study, all the experiment was carried out using aged male Swiss albino mice weighing between $30-35 \mathrm{~g}$ were used. The animals were housed under standard conditions of temperature $\left(24 \pm 2^{\circ} \mathrm{C}\right)$ and relative humidity (30-70\%) with a $12: 12 \mathrm{~h}$ lightdark cycle. They were maintained on standard pellet chow diet (Ashirwaad Industries Private Ltd. Roped, India) and water ad libitum. The experimental protocol was approved by the Institutional Animal Ethical Committee (GLAIPR/CPCSEA/IAEC/2016/ R6) and the care of animals was taken as per the standard guidelines of CPCSEA.

\section{Drug and Chemicals}

Piracetam was purchased from UCB India Pvt. Ltd., India DTNB (5, 5 dithiobis 2-nitrobenzoate and ace- 
tyl thiocholine were purchased from Sigma Aldrich, Lt, Louis, MO, U.S.A., Celecoxib from Himedia Laboratories, Pvt. Ltd, Mumbai, India and thiobarbituric acid from Chemsworth, Pvt. Ltd, India. All the reagents used in the present study were of analytical grade.

\section{Plant Materials}

The dried fruits of Sesbania grandiflora were purchased from local market of Kanpur U.P., India and authenticated (specimen no. LWG-006) by the expert of botany from National Botanical Research Institute, Lucknow U.P., India.

\section{Preparation of Extracts}

The dried fruits of Sesbania grandiflora were grinded in the mixer and powder was pass through sieve number twelve and packed in air tight container for further use. The powder was packed into soxhlet column and succively extracted with petroleum ether $\left(60-80^{\circ} \mathrm{C}\right)$, chloroform $\left(50-60^{\circ} \mathrm{C}\right)$ and ethanol $\left(78-90^{\circ} \mathrm{C}\right)$. The extracts were concentrated under reduced pressure and subjected for phytochemical analysis as per the previously described procedure; ${ }^{13}$ dried extracts were packed in air tight container and kept in refrigerator for further study.

\section{Acute Toxicity Studies}

Acute toxicity studies of ethanolic extract of SG (ESG) was performed as per the OECD guidelines 425 . The limit test was done using a limit dose of $2000 \mathrm{mg} / \mathrm{kg}$. at a dose of $50-2000 \mathrm{~g} / \mathrm{kg}$. Moreover, the experimental animals did not show any sign gross behavioral, neurological or autonomic toxic effect were observed after $3 \mathrm{~h}$ administration of ESG and no any lethality were observed from $24 \mathrm{~h}$ to 14 days.

\section{Drug administration}

Healthy swiss albino mice were divided in to 5 groups and each group having 6 animals. Group I served as positive control group and group II served as Disease control group or celecoxib treated group and treated with celecoxib $100 \mathrm{mg} / \mathrm{kg}$ p.o. for 9 days. Group III and IV served as drug treated group and pretreated for 14 days with ESG 200 and $400 \mathrm{mg} /$ $\mathrm{kg}$ p.o. doses respectively then treated with celecoxib same as II group. Group $V^{\text {th }}$ served as standard drug treated group and treated with Piracetam $200 \mathrm{mg} / \mathrm{kg}$ i.p. after $30 \mathrm{~min}$ of celecoxib $100 \mathrm{mg} / \mathrm{kg}$ p.o. administration. ${ }^{14,15}$

\section{Morris's Water Maze}

For the determination of the effect of ESG on memory of experimental animals, Morris water maze was used. It is one of the most commonly used animal models to test memory. The test was conducted according to the procedure and the parameters described by morris1984. The scored parameter escape latency time (ELT) and time spent in target quadrant (TSTQ) were recorded with the help of ANY Maze software. ${ }^{16-20}$

\section{Dissection and Homogenization}

After behavioral assessments, the animals were sacrifice by cervical dislocation. The brains were removed and each brain was separately placed in ice and rinsed with ice cold isotonic saline. A (10\% w/v) brain tissue homogenate was prepared in $0.1 \mathrm{M}$ phosphate buffer $(7.4 \mathrm{pH})$. The homogenate was centrifuged at $3000 \mathrm{rpm}$ for $15 \mathrm{~min}$ at $4^{\circ} \mathrm{C}$ and aliquots of supernatant were separated and used for biochemical estimation. ${ }^{21}$

\section{Acetylcholine Esterase Activity}

AchE inhibitory activity of ESG was measured by method of Ellman et al., 1916.22 The homogenates were centrifuged at $1000 \mathrm{rpm}$ for $10 \mathrm{~min}$ at $4^{\circ} \mathrm{C}$ and supernatant was used as a source of enzyme in AchE assay. For this $25 \mu \mathrm{l}$ of acetyl thiocholine iodide, $75 \mu \mathrm{l}$ of dithiobisnitrobenzoic acid (DTNB) and $75 \mu \mathrm{l}$ of tris $\mathrm{HCl}$ were added in test tube and incubated for $5 \mathrm{~min}$ at $25^{\circ} \mathrm{C}$. Then the absorbance was measured at $405 \mathrm{~nm}$ using a spectrophotometer. The enzyme activity was expressed as the " $\mathrm{n}$ " moles of substrate hydrolyzed $/ \mathrm{min} / \mathrm{mg}$ of protein.

\section{Thiobarbituric Acid Reactive Substance (TBARS) Assay}

For this $0.5 \mathrm{~mL}$ of Tris hydrochloric acid was added in $0.5 \mathrm{~mL}$ of supernatant and incubated at $37^{\circ} \mathrm{C}$ for $2 \mathrm{~h}$. After incubation $1 \mathrm{~mL}$ of $10 \%$ trichloro acetic acid was included and centrifuged at $3000 \mathrm{rpm}$ for $10 \mathrm{~min}$, and afterward $1 \mathrm{mLof} 0.67 \%$ thiobarbituric acid was added to $1 \mathrm{~mL}$ of supernatant. The tubes were kept in boiling water for $10 \mathrm{~min}$ and then cooled at room temperature. After cooling $1 \mathrm{~mL}$ of distilled water was added and absorbance was measured at $532 \mathrm{~nm}^{23}$

\section{Catalase Activity}

Catalase activity was assessed by the method of Luck (1971). In this the breakdown of hydrogen peroxide is measured. Three $\mathrm{mL}$ of $\mathrm{H}_{2} \mathrm{O}_{2}$ phosphate buffer was added in $0.05 \mathrm{~mL}$ of supernatant of the tissue homogenate and absorbance was recorded at $240 \mathrm{~nm}$ using Lab India spectrophotometer. The results were expressed as micromoles of $\mathrm{H}_{2} \mathrm{O}_{2}$ decomposed per min per mg of protein. ${ }^{24}$

\section{Estimation of Brain GSH}

The GSH content in brain was estimated spectrophotometrically at 412 $\mathrm{nm}$ using the method of Beutler et al., Briefly, the supernatant of homogenate was mixed with trichloro acetic acid $(10 \% \mathrm{w} / \mathrm{v})$ in $1: 1$ ratio. The mixture was centrifuged at $1000 \mathrm{rpm}$ for $10 \mathrm{~min}$ at $4^{\circ} \mathrm{C}$. The supernatant obtained $(0.5 \mathrm{~mL})$ was mixed with $2 \mathrm{~mL}$ of $0.3 \mathrm{M}$ disodium hydrogen phosphate, then $0.25 \mathrm{~mL}$ of $0.001 \mathrm{M}$ freshly prepared DTNB was added and absorbance was noted by using spectrophotometer at $412 \mathrm{~nm} .{ }^{25}$

\section{Speroxide Dismutase}

SOD activity was assessed by the method of Kakkar et al. $0.1 \mathrm{~mL}$ of $186 \mu \mathrm{M}$ phenazinemethosulpahte and $1.2 \mathrm{~mL}$ of $0.052 \mathrm{mM}$ sodium pyrophosphate buffer $(\mathrm{pH} 7.0)$ and $0.3 \mathrm{~mL}$ of supernatant of tissue homogenate was added. To start enzyme reaction $0.2 \mathrm{~mL}$ of $780 \mu \mathrm{M}$ NADH was added as a catalyst in reaction mixture and incubated for one min. After incubation $1 \mathrm{~mL}$ of glacial acetic acid was added to stop the enzyme reaction. ${ }^{26}$

\section{Statistical Analysis}

All the values of the experimental results were expressed as mean \pm standard error of mean (SEM). One-way ANOVA followed by Bert lets multiple comparison tests repeated measure were applied for the statistical analysis of all the parameters. Graph Pad Prism (version 5.03) software was used for all statistical analysis and $\mathrm{p}<0.05$ was considered as significant.

\section{RESULTS}

\section{Acute toxicity studies and phytochemical analysis:}

Administration of ESG up to the dose of $2000 \mathrm{mg} / \mathrm{kg}$ b.w in mice did not show any harmful effect on peripheral and central nervous system up to the 14 days of observation. Phytochemical screening of the different extracts of $S G$ showed the presence of carbohydrate steroids, glycoside, flavonoid, tannin, saponin and phenolic compounds Table 1 .

The result of the Morris's water maze shows that the treatment of Celecoxib (100 mg/kg p.o.) significantly $\mathrm{p}<0.05$ increase the escape latency time when compared to normal control group. However, the treatment of Piracetam (200 mg/kg) and ESG 200 and $400 \mathrm{mg} / \mathrm{kg}$ significantly decrease the escape latency time when compare to disease control group. As shown in Figure 3 that there was significant reduction $p<0.001$ was observed in time spent in target quadrant by the celecoxib treated mice. However, the treatment of piracetam $200 \mathrm{mg} / \mathrm{kg}$ and ESG 400 $\mathrm{mg} /$ show significant $\mathrm{p}<0.05$ increment in time spent in target quadrant when compared with normal control group. Figure 1,2,3. 
Table 1: Result of Phytocchemical analysis of various extracts of Sesbania grandiflora.

\begin{tabular}{ccccc}
\hline S.No. & Plant constituent & $\begin{array}{c}\text { Pet. ether } \\
\text { extract }\end{array}$ & $\begin{array}{c}\text { Chloroform } \\
\text { extract }\end{array}$ & $\begin{array}{c}\text { Ethanol } \\
\text { extract }\end{array}$ \\
\hline 1 & Carbohydrates & + & -- & + \\
2 & Alkaloids & -- & + & + \\
3 & Steroids & + & + & + \\
4 & Tannin and & -- & + & + \\
& polyphenols & & & + \\
5 & Flavonoid & -- & + & + \\
6 & Amino acids & - & -- & + \\
7 & Saponins & + & -- & + \\
8 & Proteins & -- & -- & + \\
9 & Glycosides & -- & -- & + \\
\hline
\end{tabular}

$+=$ Presence $-=$ Absent

Morris's water maze

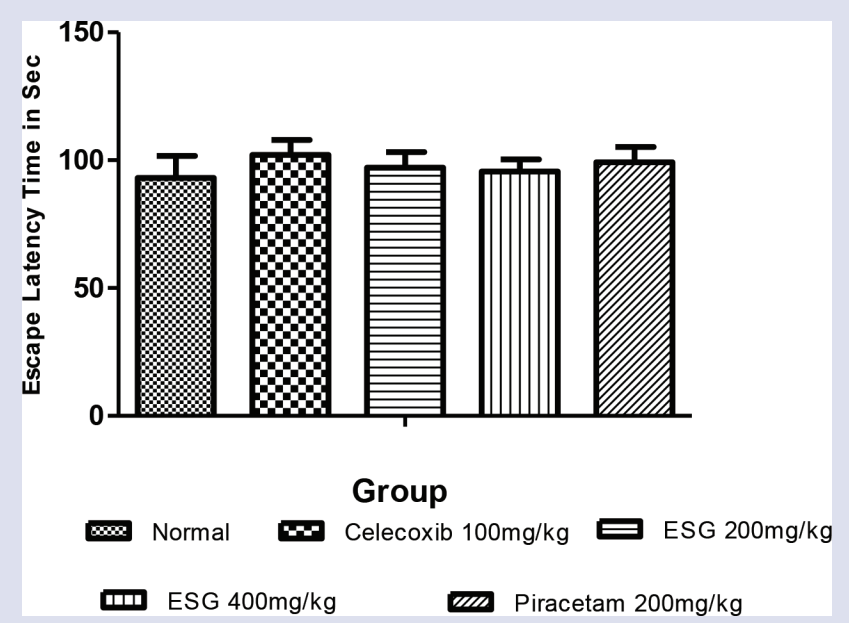

Figure 1: Effect of ESG and Piracetam on escape latency time on $1^{\text {st }}$ day. $n=6$ Results are expressed as mean \pm SEM. Data was analyzed by One-way ANOVA followed by Bertlet's test.

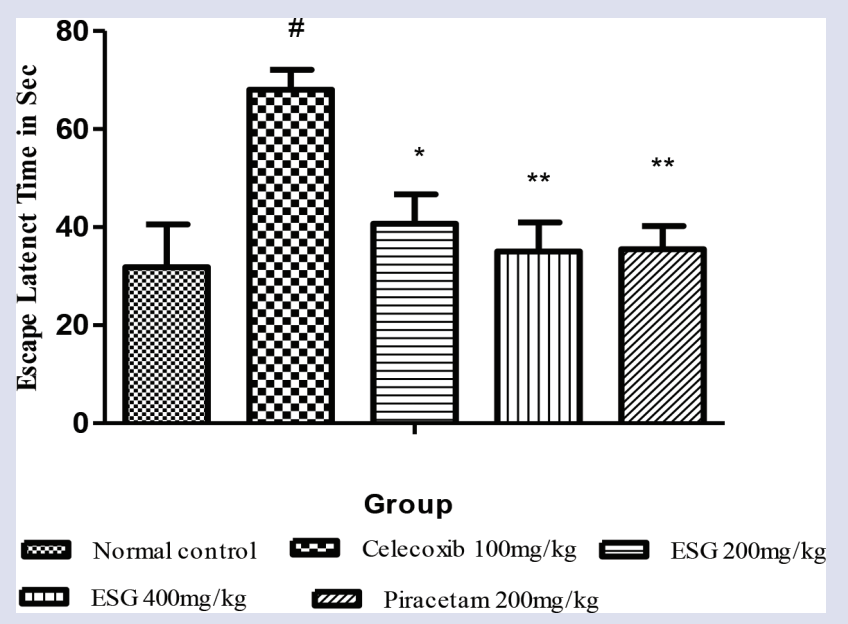

Figure 2: Effect of ESG and Piracetam on escape latency time on $4^{\text {th }}$ day. $(n=6)$ Results are expressed as mean \pm SEM. Data was analyzed by One-way ANOVA followed by Bertlet's test " $P<0.05$ vs disease control group and ${ }^{\#} \mathrm{P}<0.05$ vs normal control group.

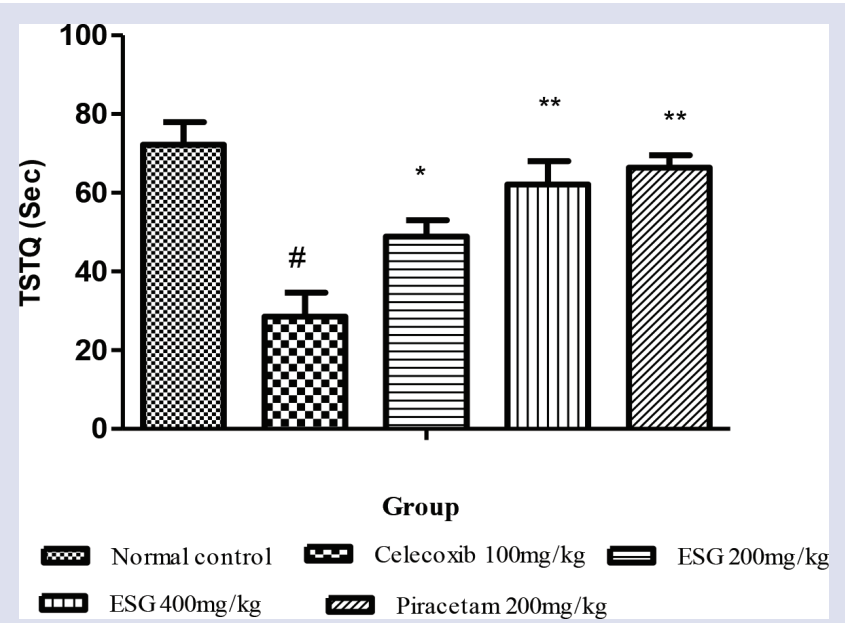

Figure 3: Effect of ESG and Piracetam on TSTQ. $(n=6)$ Results are expressed as mean \pm SEM. Data was analyzed by One-way ANOVA followed by Bertlet's test ${ }^{*} \mathrm{P}<0.05,{ }^{* *} \mathrm{P}<0.001$ vs disease control group and $" \mathrm{P}<0.001$ vs normal control group.

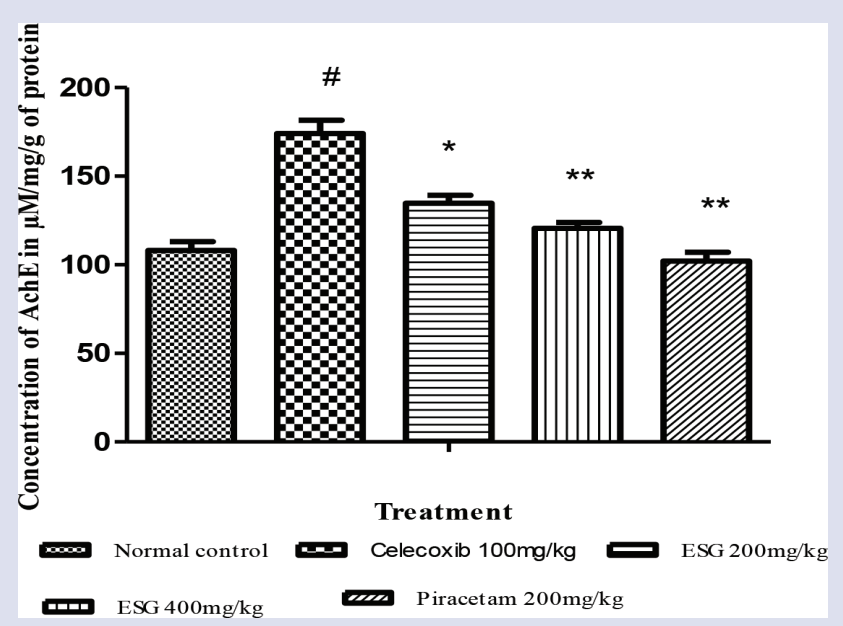

Figure 4: Effect of ESG and Piracetam on AchE activity. $(n=6)$ Results are expressed as mean of AchE concentration \pm SEM. Data was analyzed by One-way ANOVA followed by Bertlet's test ${ }^{*} P<0.05$, " $P<0.001$ vs disease control group and ${ }^{*} P<0.001$ vs normal control group.

\section{Estimation of Biochemical Parameters Acetylcholine Esterase Activity}

After performing the behavioral parameter, the AchE activity was measured by the method of Ellman et al. There was significant $\mathrm{p}<0.05$ increase in brain AchE level was found in the Celecoxib treated animals when compared with normal control group. Piracetam and ESG treatment significantly $\mathrm{p}<0.05$ inhibited the brain AchE level compared to their corresponding celecoxib group. Figure 4.

\section{Thiobarbituric Acid Reactive Substance (TBARS) Assay}

A significant increment $(p<0.05)$ in the brain malondialdehyde level was observed in Celecoxib treated mice was found when compared to the normal control group Figure 5. Treatment of ESG and piracetam significantly $(p<0.05)$ decrease the brain MDA level compared to their corresponding celecoxib group. 


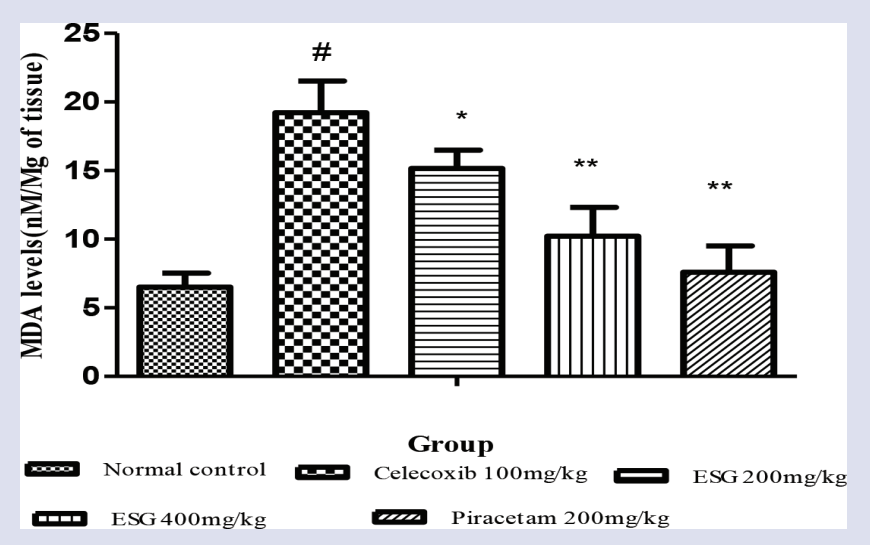

Figure 5: Effect of ESG and Piracetam MDA level $(n=6)$ Results are expressed as mean of MDA level \pm SEM. Data was analyzed by One-way ANOVA followed by Bertlet's test ${ }^{*} \mathrm{P}<0.05,{ }^{* *} \mathrm{P}<0.001$ vs disease control group and $" \mathrm{P}<0.001$ vs normal control group.

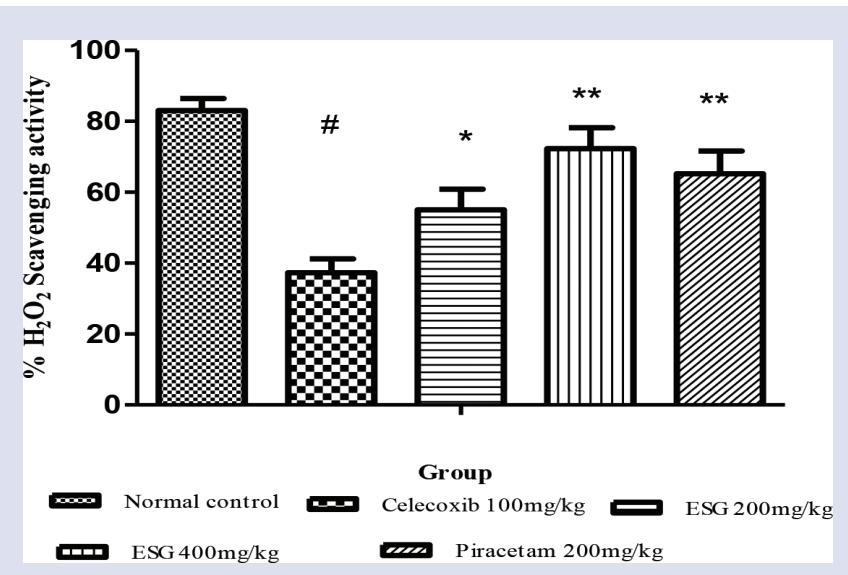

Figure: 7 Effect of ESG and Piracetam on $\mathrm{H}_{2} \mathrm{O}_{2}$ scavenging activity. $(n=6)$ Results are expressed as mean percentage of $\mathrm{H}_{2} \mathrm{O}_{2}$ scavenging level \pm SEM. Data was analyzed by One-way ANOVA followed by Bertlet's test ${ }^{*} \mathrm{P}<0.05,{ }^{* *} \mathrm{P}<0.001$ vs disease control group and $\mathrm{P} P<0.001$ vs normal control group.

\section{Antioxidant activity}

There was significant decrease in the SOD, GSH and catalyase activity was found when compared to normal control group. Treatment of piracetam significantly restores the level of GSH, SOD and catalayse activity in experiment animals when compared with disease control group. ESG $400 \mathrm{mg} / \mathrm{kg}$ significantly $(p<0.001)$ prevented the decrement in level of above enzyme Figure 6,7,8 when compared to disease and piracetam treated animals. However, pretreatment of ESG $200 \mathrm{mg} / \mathrm{kg}$ could not significantly increase the level of GSH, SOD and catalayse when compared to piracetam treated animals.

\section{DISCUSSION}

Plant extracts having numerous dynamic compounds which are responsible for its widespread therapeutic activities and minimal side effects in compare to synthetic molecules. ${ }^{27}$ Phytochemical screening of the different extracts of Sesbania grandiflora revealed the presence of saponin glycosides, flavonoid, tannin and phenolic compounds. In the present study ethanolic extracts have been chosen due to its expected flavonoid content and

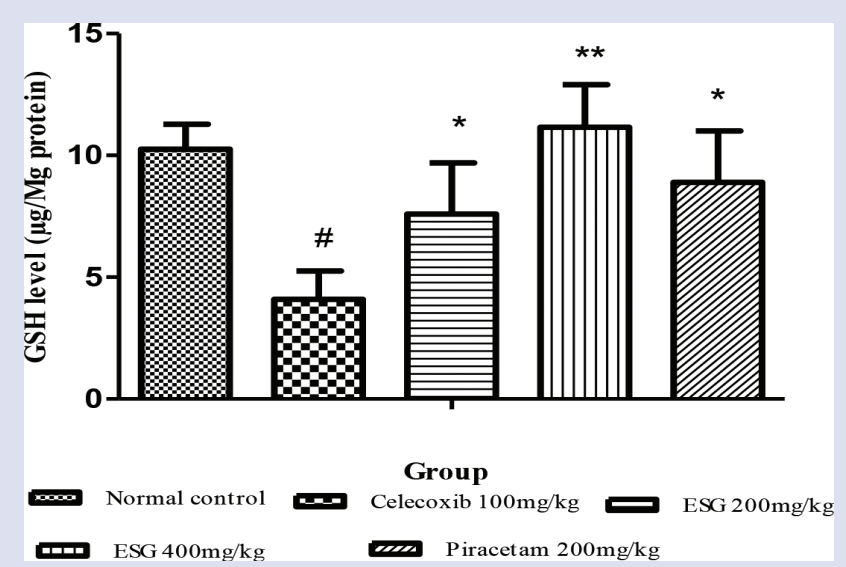

Figure: 6 Effect of ESG and Piracetam on GSH level. $(n=6)$ Results are expressed as mean of GSH concentration \pm SEM. Data was analyzed by One-way ANOVA followed by Bertlet's test ${ }^{*} P<0.05,{ }^{* *} P<0.001$ vs disease control group and ${ }^{\#} \mathrm{P}<0.001$ vs normal control group.

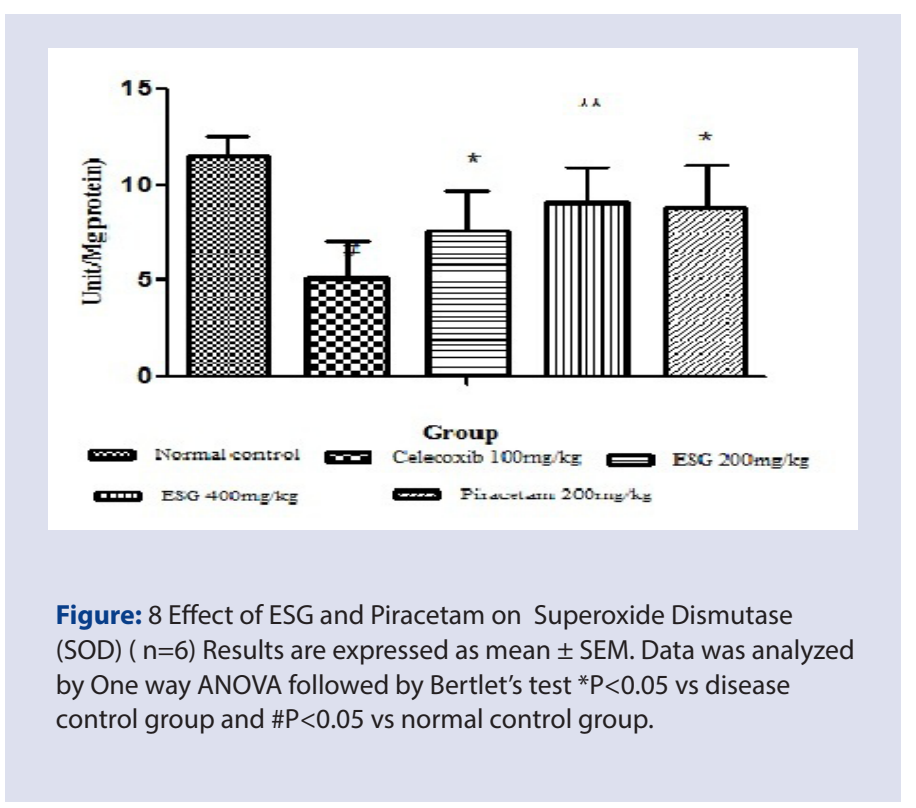

good relationship between phenolics and antioxidant activity shown by the researchers. ${ }^{28}$

In the current study Morris's water maze was used as a behavioral model to evaluate the impact of extract on memory. In this model decline in escape latency time and expansion in time spent in target quadrant demonstrate a change in memory and learning. ${ }^{29}$ Mice treated with celecoxib demonstrated more delayed escape latency time than mice from the normal control group. Pretreatment of ESG and piracetam for nine days significantly $(\mathrm{p}<0.001)$ mitigated the celecoxib induced amnesia in mice as indicated by decrease the escape latency time and increase in time spent in target quadrant (TSTQ) in Morris's water maze test.

In addition to impairment of learning and memory function there is also enhancement of brain AchE activity occurs in celecoxib $(100 \mathrm{mg} / \mathrm{kg}$ for 9 days; 5days persistent and 4 back to back days) treated mice. A number of studies have reported that the cholinergic system play a important role in learning and memory. ${ }^{30}$ The brain acetylcholine level determines the memory functions and AchE are responsible for deactivating brain Ach. ${ }^{31,32}$ It is an enzyme of carboxylesterase family that cata- 
lyzes the breakdown of ACh and of some other choline esters that act as neurotransmitters. ${ }^{33}$ The data of the current study revealed that the AchE activity was decreased in ESG treated mice, this decrement was nearly equally significant $(P<0.05)$ to the Piracetam group. Thus, it can be said that the ant amnesic effect of ESG might be due to changes in cholinergic system.

Further this investigation additionally assessed whether such impairment in memory function by celecoxib is related with changes in oxidative marker. Reactive oxidative species (ROS) are produced ceaselessly in nervous system. The neurons are especially sensitive for oxidative damage and have high oxygen utilization, as compare to other organs. ${ }^{34} \mathrm{MDA}$ is most willingly used assay for the product of lipid peroxidation. ${ }^{35}$ Treatment of ESG significantly attenuated the elevated level of MDA in celecoxib treated animals. Glutathione is an endogenous antioxidant presenting in the reduced form within the all mammalian cells ${ }^{36}$ and react with free radicals and prevent generation of hydroxyl free radicals. ${ }^{37}$ The diminished level of GSH activity in Celecoxib-treated animals shows that there is an increased generation of free radicals and decreased activity of glutathione system in battling oxidative stress. Administration of ESG restores the level of catalase, SOD and GSH in celecoxib treated rats. So, it can be said that the ESG have neuroprotective activity in experimental animals and this protective effect could be due to the presence of phytochemicals such as flavonoids and phenolic compounds, which modify the release of acetylcholine synthesis or inhibit the acetylcholineesterase enzyme $e^{38,39}$ or potentiate the synthesis of antioxidant enzyme which is beneficial for neuronal injury. ${ }^{40}$

\section{CONCLUSION}

The present study has shown that the significant neuroprotective effect at the doses of 200 and $400 \mathrm{mg} / \mathrm{kg}$ in mice. This could be due to the presence of wide range of phytochemical which fight against the free radicals.

\section{REFERENCES}

1. Mansa S, Raju AB. Anti-amnesic activity of Solanum melongena $L$ extract. Postepy fitoterpii. 2014;1:1-7.

2. Vijayalakshmi, Adiga S, Bhat $P$, Chaturvedi A, Bairy KL, Kamth S. Evaluation of the effect of Ferula asafetida Linn. Gum extract on learning and memory in wistar rats. I J Pharmacology. 2011;44(1):82-7. https://doi.org/10.4103/02537613.91873; PMID:22345876.

3. http://www.alzheimers.net/2013-12-11/alzheimers-global-epidemic-by-2050/ assessed on dated 25/4/2017.

4. Louise R, Eugene T, John PT. Dementia: timely diagnosis and early intervention BMJ. 2015;300:h3029. https://doi.org/10.1136/bmj.h3029.

5. Konstantina GY, Sokratis GP. Current and futue treatment for alzhemier disease. Thera Adv Neurological Disorders. 2013;6(1):19-33. https://dx.doi.org/ 10.1177\%2F1756285612461679; PMCID: PMC3526946

6. Cummings JL. Alzhemiers disease. New England J Med. 2004;351:56-7. https://doi.org/10.1056/NEJMra040223; PMID:15229308.

7. Sariva ME, Ulisees AVR, Ribeiro DA, Oliveira LGS, Macedo DG, Sousa FFD. Plant species as a therapeutic resource in areas of the savanna in the state of Pernambuco, Northeast Brazil. J ethnopharmacology. 2015;171:141-53. https:// doi.org/10.1016/j.jep.2015.05.034.

8. Joshi $H$, Parle M. Zingiber officinale: Evaluation of its Nootropic effect in mice. African J Trad Complementary Alter Med. 2006;3(1):64-74.

9. Burkar BB, Dayom DW, Uguru MO. The Growing Economic Importance of Medicinal Plants and The Need for Developing Countries to Harness From it: A Mini Review. IOSR J Phar. 2016;6(5):42-2.

10. Patil RB, Nanjwade BK, Manvi FV. Effect of Sesbania grandiflora and Sesbania sesban bark on carrageenan induced acute inflammation and adjuvant-induced arthritis in rats. Inter J Pharmacologic Sci. 2010;1(1):75-100.

11. Nadkarni AK, Nadkarni KM. Indian material medica, Bombay Popular prakashan. 1: 1999.

12. Kasture VS, Deshmukh VK, Chopde CT. Anxiolytic and anticonvulsive activity of Sesbania grandiflora leaves in experimental animals. Phytotherapy Res. 2002;16(5):455-60. https://doi.org/10.1002/ptr.971; PMID:12203267

13. Khandelwal KR. Practical Pharmacognosy, Nirali prakashan. 2001.

14. Kukar T, Murphy MP, Eriksen JL, Sagi SA, Weggen S, Smith TE, et al. Diverse compounds mimic Alzheimer's disease-causing mutations by augmenting
A 342 production. Nat Med. 2005;11(5):545-50. https://doi.org/10.1038/nm1235; PMID:15834426

15. Tathe PR, Bheemachari V, Uplanchiwar A, Modi R, Gahane SK, Jain R. Hepatoprotective Activity of Fruit Extract of Sesbania grandiflora, (Pers). Pharmacology. 2010;3:423-30.

16. Morris R. Developments of a water maze procedure for studying spatial learning in the rat. J Neuroscience Methods. 1984;11(1):47-60.

17. Parle M, Singh N. Animal models of testing memory. Asia pacific J Pharmacology 2004; 16:101-20.

18. Sharma B, Puri M, Tiwary AK, Singh N, Jaggi AS. Anti-amnesic effect of stevioside in scopolamine-treated rats. I J Pharmacology. 2010;42(3):164-7. DOI: $10.4103 / 0253-7613.66840$

19. Sharma B, Singh N, Singh M. Modulation of celecoxib and streptozotocin induced experimental dementia of Alzheimer's disease type by pitavastatin and donepezil. J Psychopharmacology. 2008;22(2):162-71. https://doi.org/ 10.1177/0269881107081553; PMID:18208924

20. Sharma B, Singh N. Experimental hypertension induced vascular dementia: Pharmacological, biochemical and behavioral recuperation by angiotensin receptor blocker and acetylcholinesterase inhibitor. Pharmacology Biochemistry Behavior. 2012;102(1):101-8. https://doi.org/10.1016/j.pbb.2012.03.029; PMID 22507914

21. Goverdhan P, Sravanthi A, MamathaT. Neuroprotective effects of Meloxicam and Selegiline in scopolamine-induced cognitive impairment and oxidative stress. Inter J Alzheimer's Dis. 2012;(2012): Article ID 974013. doi:10.1155/2012/974013.

22. Ellman GL, Courtney DK, Andres V. Feathstone RM. A new and rapid colorime teric determination of acetylcholinesterase activity. Biochemistry Pharmacology. 1961;7:88-95. https://doi.org/10.1016/0006-2952(61)90145-9.

23. Talpate KA, Bhosale UA, Zambare MR, Somani RS. Neuroprotective and nootropic activity of Clitorea ternatea Linn. (Fabaceae) leaves on diabetes induced cognitive decline in experimental animals. J Pharm Bioallied Sci. 2014;6(1):48-55 doi:10.4103/0975-7406.124317; PMCID: PMC3895294

24. Kumar A, Naidu PS, Sehgal N, Padi SSV. Effect of curcumin on intracerebroventricular colchicine-induced cognitive impairment and oxidative stress in rats. J Med Food. 2007;10(3):486-94. https://doi.org/10.1089/jmf.2006.076; PMID:17887943

25. Shamnas M, Ratendra R, Teotia UVS. Neuroprotective activity of methanol extract of Salvia officinalis flowers in dementia related to Alzheimer disease. Der pharma sinica. 2014;5(2):29-38.

26. Kakkar P, Das B, Viswanathan PN. A modified spectrophotometric assay of superoxide dismutase. Indi J Biochemistry Biophysics. 1984;21:130-2.

27. Mouhseen L. The success of natural product in drug discovery. Pharmacology and Pharmacy. 2013;4(3A):17-31. http://dx.doi.org/10.4236/pp.2013.43A003.

28. Imran M, Khan H, Shah M, Khan R, Khan F. Chemical composition and antioxidant activity of certain Morus species. J Zhejiang Univ Sci B. 2010;11(12):973-80. https://doi.org/10.1631/jzus.B1000173, PMID: 21121077.

29. Dhingra D, Kumar V. Memory enhancing activity of palmatine in mice using elevated plus maze and Morris water maze Advances in pharmacological sciences. 2012;2012: http://dx.doi.org/10.1155/2012/357368 Paper ID 357368.

30. Ismail OI, Tota SK, Adeyemi OO, Agbaje EO, Shukla R. Protective effect of cnestis ferruginea and its active constituents on scopolamine induced memory impairment in mice: a behavioral and biochemical study. J Pharmaceutical Bio. 2013;51(7):825-35. http://dx.doi.org/10.3109/13880209.2013.767360.

31. Sobharani R, Pal AK, Bhattacharjee A, Mitra S, Aguan K. Screening Indigenous medicinal Plants of Northeast India for their anti - Alzhemier Properties. Phar macognosy J. 2017;9(1):46-54.

32. Joshi H, Kaur N, Chauhan J. Evaluation of Nootropic effect of Argyreia speciosa in mice. J Health. 2007;53(4):382-8. hhttps://doi.org/10.1248/jhs.53.382...

33. Qi B, Zhang L, Zhang Z, Ouyang J, Huang H. Effects of ginsenosides-Rb 1 on exercise-induced oxidative stress in forced swimming mice. Pharmacognosy Mag [serial online] 2014 [cited 2017 Jul 31];10(40):458-63. Available from: http:// www.phcog.com/text.asp?2014/10/40/458/141818.

34. Colovic MB, Krstic DZ, Pasti TDL, Bondzic AM, Vasic VM. Acetylcholine esterase inhibitor: Pharmacology and toxicology. Current Neuropharmacology. 2013;11(3):315-35. https://dx.doi.org/10.2174\%2F1570159X11311030006; PMCID PMC3648782

35. Jeong EJ, Lee KY, Kim SH, Sung SH, Kim YC. Cognitive-enhancing and antioxidant activities of iridoid glycosides from Scrophularia buergeriana in scopolamine-treated mice. Eur J Pharmacology. 2008;588(1):78-84. https://doi. org/10.1016/j.ejphar.2008.04.015 PMID:18462717.

36. Shrivastava S, Uthra C, Rashil MS, Shukla S. Protective Role of Kaempferol Against Acrylamide Intoxication. Free Radicals Antioxidants. 2017;7(1):36-42.

37. Lobo V, Patil A, Phatak A, Chandra N. Free Radical, antioxidants and functional foods: Impact on human health. Pharmacognosy Reviews. 2010;4(8):118-26. https://dx.doi.org/10.4103\%2F0973-7847.70902; PMCID: PMC3249911.

38. Zhu SY, Dong Y, Tu J, Zhou Y, Zhou XH, Xu B. Silybum marianum oil attenuates oxidative stress and ameliorates mitochondrial dysfunction in mice treated with D-galactose. Pharmacognosy Mag. 2014;10 Supple 1:92-9

39. Orhan I, Sener B. Acetylcholinesterase inhibitors from natural resources. FABAD J Pharm Sci. 2003;28:51-8 
40. Ahmed F, Narendra SCJN, Manjunath S. Acetylcholine and memory-enhancing activity of Ficus racemosa bark. Pharmacognosy Res [serial online] 2011 [cited 2017 Jul 31];3(4):246-9. Available from: http://www.phcogres.com/text. asp?2011/3/4/246/89744
41. David V, Katerina V, Ana RM, Catarina R, Jeremy PES. The Neuroprotective potential of flavonoid: a multiplicity of effects. Genes Nutr. 2008;3(3-4):115-26. https://dx.doi.org/10.1007\%2Fs12263-008-0091-4; PMCID: PMC2593006.

\section{GRAPHICAL ABSTRACT}

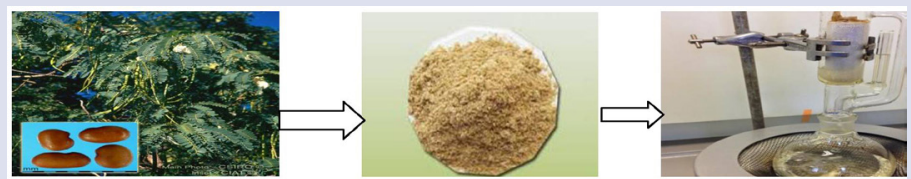

Sesbania grandiflora Seed

Dry Seed Powder
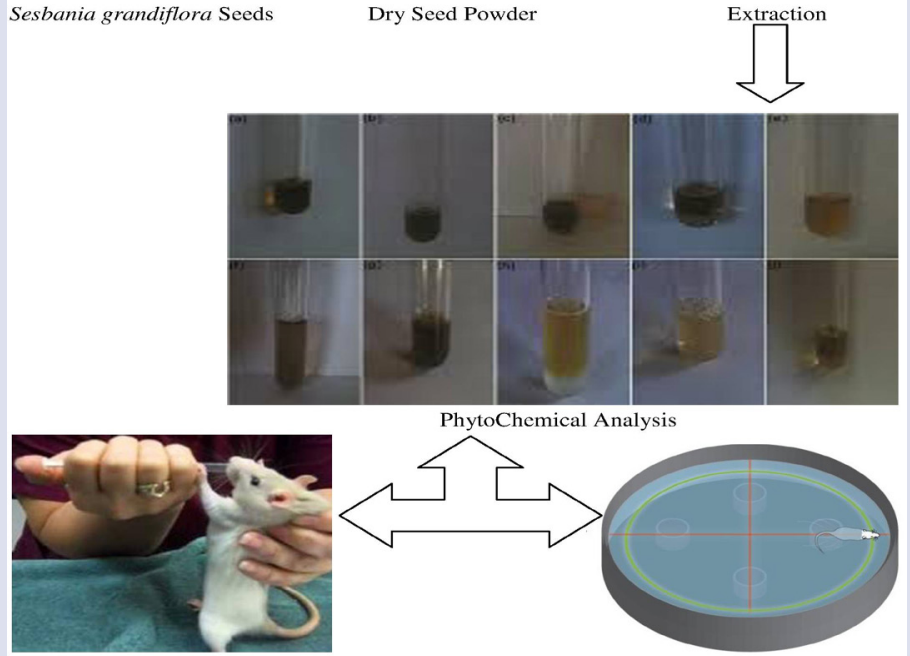

PhytoChemical Analysis

Acute Toxicity Study

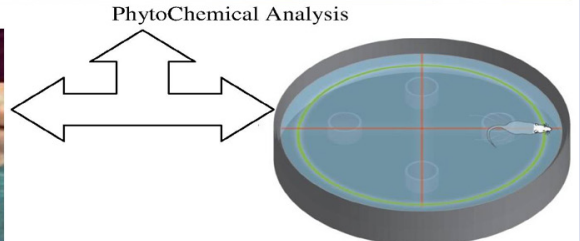

Morris Water Maze

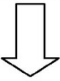

Biochemical Estimation

Cite this article: Semwal BC, Murti Y, Verma M, Yadav HN. Neuroprotective Activity of Sesbania grandifolara Seeds Extract Against Celecoxib Induced Amnesia in Mice. Pharmacog J. 2018;10(4):747-52. 